\title{
Verbal Clause in Siladang Language
}

\author{
Purwanto Siwi ${ }^{1}$, Paitoon M. Chaiyanara ${ }^{1}$, Eddy Setia ${ }^{1}$, Masdiana Lubis ${ }^{1}$ \\ ${ }^{I}$ Post-Graduate Department of Linguistics, Faculty of Cultural Sciences, University of Sumatera Utara, Medan, \\ Indonesia
}

*Corresponding Author: Purwanto Siwi, Post-Graduate Department of Linguistics, Faculty of Cultural Sciences. Universitv of Sumatera Utara. Medan. Indonesia

\begin{abstract}
The primary purpose of this study is to determine the characteristics of verbal clause in Siladang language which is used by its native speakers in small scale. This study was conducted in two villages, Sipaga-paga and Aek Banir, and its data was obtained from the help of local people. Respondents indicated their preferences through oral communication; the interviews were recorded on audiotape and videoshooting. This study implies that the clause structure of the Siladang language consists of clause structures with nonverbal and verbal predicates. The first may appear in the forms of clauses with adjectival, nominal, numeral, and prepositional phrase predicates. This language does not have a copulative verbs so these verbs are never appearing in the clauses of nonverbal predicates. Meanwhile, the second may have intransitive, ditransitive, and extended transitive. The results provide some support for the problem identification which was prepared before this study began.
\end{abstract}

Abbreviations: EL=ethnic language; SL=Siladang language; BI=Bahasa Indonesia; ML=Mandailing language; $S$-V-O=subject, verb, object; Sal=Sabu language; $S G=$ singular; $P R E F=$ prefix; Prep=preposition; $N E G=n e g a t i o n / n e g a t i v e ; \quad P A R=$ particle; GEN=genitive; DO=direct object; IO=indirect object; $S$ - $P$ $O=$ subject, predicate, object, $A=$ argument of agent; S=sole argument; IL=Indonesian language; Min=Minangkabau; Jav=Javanese; CM=classicl Malay; Vtr=verb transitive; NP=noun phrase; $S P=$ Siladang people; $1=$ first $; 2=$ second; $3=$ third; $P L=$ plural; $D E F=$ definitive; $V C l=v e r b a l$ clause; $N P=$ noun phrase; $V P=$ verbal phrase; $P P=$ prepositional phrase.

Keywords: Verbal clause, Siladang, transitive, intransitive, extended transitive

\section{INTRODUCTION}

As the priceless asset of a nation, an ethnic language (EL) should be preserved since through language a nation will be able to maintain its local culture. In principle, an EL can play its role to act as the identity of a community group, which is always respected and even praised by its native speakers, like the Siladang language (SL) which is only found in Sipaga-paga and Aek Banir villages. They are located in Panyabungan Sub-district, Mandailing Natal Regency, North Sumatera Province (Indonesia). In fact, although it is minority language, the SL posits itself as the symbol of regional pride, identity and communication tool for the SL speakers as well as for the supportve media for the Bahasa Indonesia (BI) which of course becomes the formal language of instruction in schools.

Although the SL is used as a means of communication but, because of heterogeneous population, its influence, function and position shows a decline in its function. Mandailing language (ML) is dominantly used as in traditional markets, at religious ceremonies such as marriage, death and tradition. The decrease is also influenced by BI, television and newspapers. Thus, the efforts to preserve the SL, for example, its structure, form, meaning, function, and value is a must to increase the number of bilingual speakers. The SL has its own peculiarities and belongs to the MalayoPolynesian family. The native speakers speak quickly and use vowels $0, \partial$, and $a$ a as shown in the examples molsngksh 'to go', ponto 'beach' and aə 'water'. Interestingly, different with the BI, the SL has the consonant $v$, for example, uvong 'people', jovi 'fingers'.

Some previous researches on SL are focused on traditional and structural studies, for example, morphology, phonology, and syntax, but, this research is oriented to the typology of language, namely, clauses and sentences. The typologists basically recognize the universal grammar which tries 
to find the same features in all human languages; in addition, they also recognize the differences among languages. ${ }^{[1]}$ The study of language typology proposed by Comrie is a form of reaction to the theory of generative transformation which is based on the English behavior. ${ }^{[2]}$ The theory of language typology is claimed as a neutral theory for various languages. Testing the theory of typology is important to know whether the theory can be applied to determine the typology of SL.

This study is based on the Greenberg's rule which sees the effect of word order on the formation of adposition types (prepositions or postpositions) and nominal phrases involving both adjective and genetive forms. ${ }^{[3]}$ In this case, he developed a universal word order theory that divided the world's languages into three types, namely S-V-O, S-O-V, and V-S-O. He also proposed a typology which was called Basic Order which concluded that there are six sentence patterns: SVO, SOV, VSO, VOS, OSV, and OVS. Initial research by Pawiro and Siwi showed that typologically, the word order of SL was $\mathrm{S}, \mathrm{V}, \mathrm{O}$ as shown in the examples (1)-(5).
(1) Iana bisa mam-bantu dong $\mathrm{ku}$
[3SG] be able [PREF-help to [1SG]
'He/She can help me'.
(2) Oku tak mangarti
[1SG] NEG understand
S $\quad$ V
'I do not understand'.
(3) Mang-gimbal kambeng
[PREF-hit] goat
$\mathrm{V} \quad \mathrm{O}$
'To hit goat'.
(4) Ba-kojar le basi-handok le
'Please run and hide'.
(5) Bopok-ku ma-mavi dong-ku sabuoh buku
[Father-GEN] [PREF-give] [to-1SG] [a book]
$\mathrm{S} \quad \mathrm{V}$ Prep-DO IO
'My father gives me a book'.

\section{LITERARY REVIEW}

\subsection{Previous Research on Siladang Language}

Manurung et.al. brought their research on the phonology and morphology ${ }^{[4]}$ and Butar-Butar et.al. focused their attention on the morphology and syntax, such as, morphemes and their types, word classification, morphological and morphophonemic processes, types of phrases, clauses, and sentences. ${ }^{[5]}$ Pawiro and Siwi, in their preliminary research report, discussed dwellings, culture, and linguistic information; the last provides a complete picture of parts of speech. ${ }^{[6]}$ Syarfina and Sinar illustrated the prosody and recorded 26 phonemes consisting of 7 vowel phonemes and 19 consonant phonemes. ${ }^{[7]}$ Although all these studies are encouraging, they only provide preliminary descriptions and do not classify the SL on the structurally behavioral traits in terms of the syntactic typology.

\subsection{Typological Research in Indonesia}

About this issue, some linguists, such as, Verhar (1988), Artawa (1994 and 1998), Suciati (2000), Arka (2000), Jufrizal (2004, 2007 and 2009), Sawardi (2007), Yusdi (2008), Basaria (2011), Sukendar (2012), and Budiarta (2013) have given contributions. Verhaar determined the syntax of Bahasa Indonesia (BI) as the ergative-split and accusative language ${ }^{[8]}$ When doing research on Bali language, Artawa (1994 and 1998) provided explanations of grammatical relationships, valence changing mechanisms, typological and sentence analysis based on formal syntactic theory. ${ }^{[9],[10]}$ Artawa's analysis and findings are useful in this study especially in the traces of syntactic typology and typological transcription analysis. Suciati argued that the Tetun dialect of Fehan has a tendency of accusative-type language because the argument of agent (A) in the transitive verb is dominated by the sole argument $(\mathrm{S})$ of the intransitive verb. ${ }^{[11]}$ The core argument in this language is not marked with 
certain markers (e.g, prepositions). She mentioned two groups of verbs: the first corresponding to subjects and the second not corresponding to subjects. She concluded this language has an unmarked canonical sequence with the order of agents and verbs in the marked structure.

Arka who examined some aspects of split intransitive of the Indonesian languages (ILs) concluded that typologically the IL tended to have split $S$ with head marking strategy, such as, Bali, Lamholot, Tetun, and Dawan languages, or with dependent marking strategy, such as, Kolana but Aceh with both strategies. ${ }^{[12]}$ Verbal marking is usually seen with affixes with various degrees of detail. In isolation languages, such as, Sikka which has poor morphological processes especially in its affixation, the split $S$ is displayed through a sequence between $S$ and its verbal shaft. Jufrizal concluded that the basic sequence of basic clause/phrase in Minangkabau (Min) is S-V-O (or A-VP) ${ }^{[13]}$ In contrast to the views of previous scholars, he argued that Min had split-S and flow-S. Min tends to have grammatical alliance system leading to a mixed typology between accusative and ergative. About pragmatic functions, Min prioritizes the subject so its basic structure is categorized into S-P. This language works on S/A pivot, has active diathesis (as basic diathesis) and passive diathesis (as a diathesis of the derivative) and medial diathesis. Studies on Min's structure of arguments and grammatical alliances contribute to this study.

Jufrizal specifies that Min is syntactically nominative-accusative with split-S and flow-S typology. ${ }^{[14]}$ Argument structure and grammatical alliances involve simple and compound sentence/clause. Grammatical studies on subjects and subjectivity, objects, obliques, and verbal structures concluded the Min is categorized as syntactically accusative (see also Jufrizal $2009^{[15]}$ ). About Javanese (Jav) Sawardi concluded that based on pivot test, formulation can not be formulated whether it is S/A or $\mathrm{S} / \mathrm{P}$ pivots so Jav is classified as the third category that does not have pivot mechanism. ${ }^{[16]}$ The pivot in Jav can only be explained from its verbal semantics and context of discourse. Syntactically, Jav can not be grouped as accusative or ergative type. If the pivot is one of the features that the grammatical subject has, this is not accepted in Jav. In case of classical Malay (CM), Yusdi concluded that CM has the basic pattern of nominative-accusative language. ${ }^{[17]} \mathrm{CM}$ consists of active and passive diathesis with S-P-O construction mediated by Vtr + me- and Vtr + di- (which can be said to be both canonical active and passive in which the active sentence, semantically, treats grammatical subjects as agents (S/A) and, grammatically, can be changed into passive by keeping S-P-O as the basic structure. Basaria argued the basic structure of Pakpak Dairi is a clause with non-verbal and verbal predicates. ${ }^{[18]}$ The first includes the adjectiva, nominal, numeral and prepositional phrases and the second consists of verbal predicates composing of transitive and intransitive clauses.

Sukendar proved that the structure of clause in Sabu language ( $\mathrm{SaL}$ ) consists of verbal and nonverbal predicate. Nonverbal predicate clauses have nouns, adjectiva, numeralia and prepositional phrases. ${ }^{[19]}$ The usual word-order of basic clauses is SVO or AVP. The SaL predicate consists of verbal predicate with one argument in the intransitive and with two arguments in the transitive, and with three arguments in the transititive. The results of Budiarta's study reveal that the retention of the basic structure of the Kemak language clause consists of verbal predicate and non-verbal predicate clauses. ${ }^{[20]}$ The nonverbal predicate clauses can be occupied by nominal, adjectiva, numeral, and prepositional phrases. The verbal predicate clauses are dominated by intransitive and transitive verbs. Then the denunciation of predication shows that the predicate of the intransitive clause requires an element of the NP argument that serves as a grammatical subject and semantically acts as an agent or patient. Predicates with transitive verbs require two or more arguments. The presence of such arguments in transitive sentence is mandatory.

\subsection{Clause and Sentence}

Kridalaksana argued that clause are grammatical units in the form of word groups that are at least made up of subjects and predicates and have the potential to be sentences. ${ }^{[21]}$ Verhaar pointed out that a clause is a sentences consisting of a verb and a verbal phrase accompanied by one or more constituents which are syntactically related to the verb. ${ }^{[22]}$ Lapoliwa also gave his explanation that a clause refers to the unit of construction in a sentence that has the structure of predication as a single sentence in the absence of intonation. ${ }^{[23]}$ Elson and Pickett said that the meaning of a clause is the same as the meaning of a simple sentence consisting of one subject and one predicate. ${ }^{[2]}$ In this research, the researcher adopts Kridalaksana's point of view that the concept of sentence is not aligned with the concept of clause. He argued that a clause is not in the same status with a sentence 
when the reference is a minimal/elliptical sentence, for instance, the lari 'run' and pergi 'go' are not clauses because they contains no subject and predicate. If a construction contains both subject and predicate and intonation, then the construction will be a sentence when having final intonation.

\subsection{Clause Structure}

The clause structure is one of the discussions in the field of linguistics, especially in syntax. Lyons argued that syntax is only one of grammatical issues and one of the areas in linguistic studies focusing on the study of how words combine to build larger units (phrases, clauses, and sentences). ${ }^{[25]}$ Syntax is rather easily understood as the science or the study of clauses and/or sentences. The clause structure is a syntactic unit formed from the basic constituents in the form of syntactic and complementary units. In addition, the clause structure is also a bundle of interconnected meanings contained in the clause to form a complete meaning in a clause. Like many languages in the world, the predicate of a structure can be filled by verbal or nonverbal elements. Based on the predicate functions, the basic clause consists of two types, namely the basic clause with verbal and nonverbal predicate.

\section{Materials ANd Methods}

\subsection{Research Method}

This research is qualitative with descriptive approach and designed to make systematic, factual and accurate description about the SL characteristics. It uses typological method with comparative and inductive sub-methods; the nature of this study is empirical. Van Valin and La Polla stated that linguistic research is aimed at explaining linguistic phenomena. ${ }^{[26]}$ The natural data of this study were collected on the basis of existing facts or the phenomenon of language that was empirically used by SL speakers without considering right or wrong prescriptive grammar. ${ }^{[27]}$ The data should be semantically and pragmatically grammatical and acceptable (Sudaryanto. ${ }^{[28]}$ Mithun believed that the quality and quantity of data collection is highly dependent on the researchers and the time and skills of speakers. ${ }^{[29]}$

\subsection{Research Location and Time}

The research locations are Sipaga-paga and Aek Banir villages which are neighboring and administratively incorporated into the Panyabungan district, Mandailing Natal (or Madina henceforth) regency which is approximately around 800 kilometers from Medan. They were chosen because the people are mostly native speakers who use SL as a means of daily communication and determine the SL as an exclusive language within their villages but they speak Mandailing outside. The study was conducted for one year, starting from May 2014 to April 2015. Data were collected in three stages: phase 1 was held from May to August 2014, phase 2 from September to December 2014, and phase 3 from January to April 2015. Targetted places were village offices, schools, markets, shops, and stalls.

\subsection{Geography and Demography}

Geographically, the Siladang people (SP) live in the valley of Tor Sihite hills about $17 \mathrm{~km}$ from Panyabungan city. Based on census by BPS in 2008, the SP were noted to amount to 2,030 and 1,000 (or 528 families) live in Aek Banir and 1,030 (or 376 families) occupy Sipaga-paga. Data in 1975 showed the SP amounted to 1,111; some of 264 (55 families) dwelled in Sipaga-paga and 849 (171 families) resided in Aek Banir. Almost all SP live on farms and become farm laborers. The commodities planted by them are generally rubber and chocolate and they also cultivate palm sugar and broom fibers. The SL speakers are bilinguals who can use the SL and Mandailing language.

\subsection{Type and Data Source}

This research focuses on the disclosure of basic clauses with tangible verbal language (logical meaningful words) that are naturally available and acceptable. Two of three kinds of data sources are used. ${ }^{[30]}$ Four criteria of sentences, such as, well-formed and acceptable, and ill-formed and unacceptable sentences are used as the selection by the researcher ${ }^{[31]}$ When a sentence is formed according to the rules of the internal grammar of the speaker's language, the sentence must be grammatical; when a sentence is not formed on the basis of grammatical rules, it must be ungrammatical. However, very often, native speakers use less well-structured sentences and having been cross-checked, the sentences are acceptable. 
To obtain valid and reliable data, the researcher utilizes oral data sources of a number of informants who meet the following criteria: native speakers are domiciled from childhood to adulthood in Siladang, aged between 20-70 years, healthy, not having speech defect, passed from primary school, and never leave the village for more than two consecutive years. They should also have good character, speech and speech organs and are vigilant, honest, polite, willing to be an informant, and not excommunicated by the community. ${ }^{[32]}$ In this research, four key informants who come from community leaders, or chiefs were involved. This research was also supported by eight supporting informants. The determination of these key informants was very important in order to obtain valid data

\subsection{Research Instrument}

The research instrument was the researcher himself who set the focus of the research and selected informants as the data source. Questionnaires were based on what Comrie proposed. ${ }^{[33]}$

\subsection{Method and Technique of Data Collection}

Methods of data collection might include direct elicitation, recording, and checking elicitation (see ${ }^{[29]}$. Techniques of data collection were the hearing and the speech.

\subsection{Method and Technique of Data Analysis}

The agih method was used to analyze data and placed the parts of the language studied as a determinant of analysis (see ${ }^{[27]}$ ) and this method had seven advanced techniques. ${ }^{[34]}$

\section{RESULTS AND DISCUSSION}

To know more about BS verbal clauses there are two parameters, namely semantic and syntactic parameters, which can be used as a guide in relation to verbs as a function of predicate clause filler. Both parameters are applied in an integrated manner so as to produce a classification of verbs or predicates that are not in a separate form between semantic and syntactic parameters. Referring to the semantic parameter, the verb is a category that refers to the meaning of the activity (action / action and process) and circumstances. Furthermore, verbs are examined from the semantic aspect of the number of participants or arguments involved in an event or circumstance. By contrast, syntactically, a verb is a core category that is present in the predicate clause position. In addition, verbs are viewed syntactically regarding the number of core arguments that must be present in a clause. Based on the syntactic distribution, the verb is the core of the verb phrase (VP) which is also at the same time the core constituent of a clause. Verbs also have a function to determine whether or not the presence of participants or arguments in a clause exists.

The verb has a syntactic feature as a predicate involving the presence of a number of arguments in its function to form a clause. Based on the number of arguments in a clause/phrase, verbs can be distinguished from intransitive, transitive, and ditransitive. The three types of verbs produce intransitive, transitive, and bipolar constructions. A more detailed discussion of the three types of verbal clauses can be seen in the followings.

\subsection{Intransitive Clause}

Based on the main categories of function cluster predicate fillers, verbs can be classified into two, namely intransitive and transitive verbs. There are two parameters used to determine the classification of verbs. (see ${ }^{[20]}$ )

Intransitive verbs or intransitive clauses in this study refer to the same terms because they are an integral as a whole. The use of the term intransitive verb or intransitive predicate has the same meaning. Both the verb and the intransitive predicate require a single core argument in a clause construct. Seen from its semantic nature, the intransitive verbs that populate the predicate of the intransitive clause can be distinguished from the experiential verb and the action verb. The verb is a verb that has a meaning of experience and a verb of action is a verb that has a meaning of action. The semantic role which becomes the only core argument in the intransitive clause and accepts the experiential verb is referred to the experiencer, while the only core argument in the predetermined clause of the action verb is the agent. If it refers to a grammatical function, the only argument in the intransitive clause occupies a function as subject. $\left(\right.$ see $\left.^{[9]}\right)$ The intransitive clauses in SL can be seen in (6)-(10). 
(6) Oku bapacu

1SG run

'I run'

(7) Iənə manari

3SG dance

'He/She dances'

(8) Ivong molongkoh ka sikola

3PL go to school

'they go to school'

(9) Sibudok $i$ jatoh

Child DEF fall

'A child falls on the ground'

(10) $\mathrm{sks}$ teda

2SG sleep

'You sleep'

The clauses in (6)-(10) are intransitive which are predicated by intransitive verbs. Some verbs populate the predicates of the intransitive clauses, for instance, the verbs bapacu in (6), manari (7), molongksh (8), jatoh in (9), and tedə in (10). The core arguments are the oku, iənə, ivong, si budək and ıks.

Structurally, the verbs in (6)-(10) may occupy certain positions, for instance, following or preceding the core arguments. Thus, the core arguments are pre-verbal or prcdcede the verbs (predicates). Examples in (6)-(10) show that typologically the constituent order of the intransitive clause is an SV (Subject+Verbal). The clause structure (cl-str) of the intransitive verb in (8) is represented in the tree diagram 1.

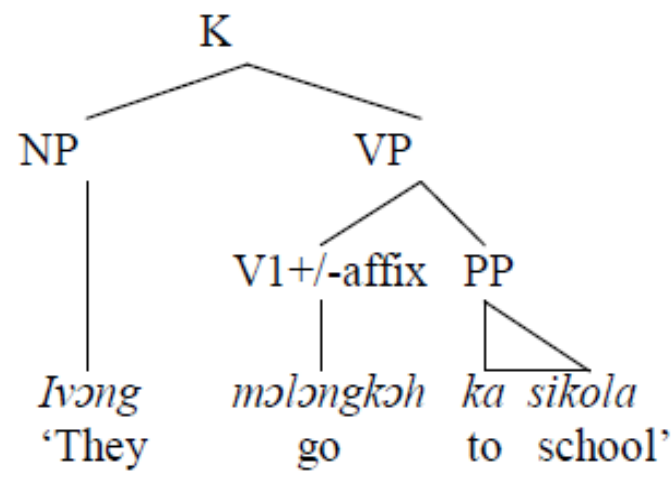

Tree Diagram1. Clause structure with intransitive verbal predicate

\subsection{Mono-transitive Clause}

Unlike the intransitive clause whose predicate requires one core argument, the transitive clause is a predicate clause (verb) requiring two core arguments. Based on the data, the SL has a mono-transitive clause whose predicate or its verb requires the presence of two core arguments. In macro perspective, these two core arguments can be called actors and undegoers (Van Valin, 1999). See the examples of mono-transitive clauses in (11)-(15):

(11) Kəmi manyuan lasinə

1PL plant chillies

'We are plant chillies'

(12) Iəna mangkael ikan

3SG to fish fish

'He/She is fishing fish'

(13) Polsdsng mamacul sovsh

Farmers cultivate paddy-field

'The farmers are cultivating their paddy-fields' 
(14) Amai mamali boju ka poken

Mother buy shirt to market

'(My) mother bought (my) shirt in the market'

(15) Kholilah manggotil podi

Kholilah cut paddy

'Kholilah is cutting paddy-plants'

The clause examples in (11)-(15) above are predicated by transitive verbs which occupy the predicates of the transitive clauses, for instance, manyuan, mangkael, mamacul, mamali, and manggotil. The verbs require the presence of two core arguments, for examples, the clauses in (11) have two core arguments, namely, kəmi and lasinə, in ${ }^{[12]} i \partial n \partial$ and ikan, in (13) polodong and sovoh, in (14) amai and boju, and in (15) Kholilah and podi. The clause structure with the transcontinental mono-transitive is shown in the tree diagram 2.

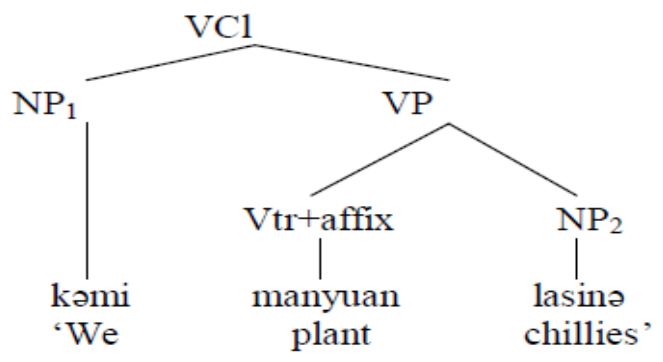

Tree Diagram2. Clause structure with mono-transitive predicate

Structurally, the verbs in (11)-(15) occupy their positions between two core arguments which functionally become the subjects and objects. They are pre-verbal and functionally considered the subjects of transitive clauses and the core arguments in the post-verbal positions functionally serve as the objects of transitive clauses. The core arguments, for instance, kəmi, iənə, polsdong, amai, and Kholilah become the subjects. Meanwhile, the core arguments, for example, lasina, ikan, sovsh, boju, and podi function as objects.

\subsection{Di-transitive Clause}

Not only has the SL a mono-transitive clause in which its verb requires the presence of two core arguments in a construction, but also it has a clause construction whose variant presents three core arguments or it is sometimes called a transititive clause. Dixon does not use the term di-transitive clause to replace clause construction that has more than two core arguments.[35] Instead, Dixon uses the term extended transitive for a di-transitive clause. In SL the construction of a di-transitive clause that presents three core arguments as seen in the examples in (16)-(19).

(16) Oku mamalikan ianə boju

1SG buy 3SG shirt

'I bought him a shirt'

(17) Iənə mambəvəkan oku manggeh

3SG bring 1SG mangosteen

'He/She brings me mangosteens'

(18) Jalms $i$ mambaikan iənə pitis

Person DEF give him money

'That person gave him/her money'

(19) Amai manungkihkan oku aə nyia

Mother make me water coconut

'(My) mother made green coconut-water for me'

The examples in (16)-(19) show three core arguments, namely, oku, iənə, ans boju in (16), iənə, oku, and manggeh in (17), jalmo i, iana, and pitis in (18) and amai, oku, and aə nyiz in (19). Specifically, clause structure with di-transitive verb is represented in the tree diagram 3. 


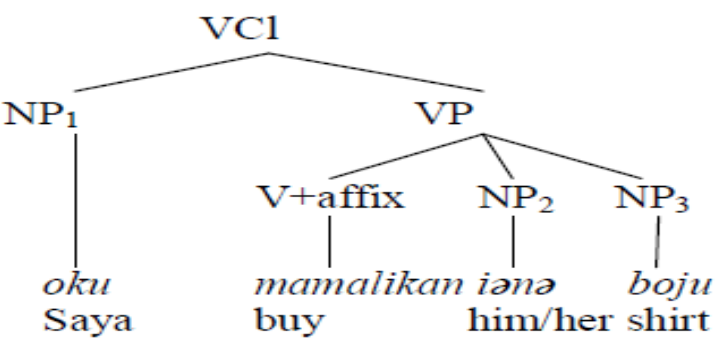

Tree Diagram 3. Clause structure with di-transitive predicate

Furthermore, the examples in (16)-(19) show that the SL has clause constructions with both more than two core arguments and morphological markers, such as, $m a-+-k a n$ which are attached to the verbs that serve to increase the presence of arguments in those clauses. The examples in (16)-(19) have alternation structures as shown in the examples (20)-(23) which are categorized as transitive clauses with predicates having two core arguments, for instance, oku and boju in (20), iana and manggeh in (21), jalmo $i$ and pitis in (22), and amai and as nyiz in (23) and are in contrast to clauses in (16)-(19) in which their core arguments undergo changes in their grammatical functions from previously as objects, such as, iənə in (16), oku in (17), iənə in (18), and oku in (19) into obliques. These obliques are marked by the presence of the preposition $d a$ in clauses

(20) Oku mamali boju da iənə

1SG buy shirt Prep 3SG

'I bought shirt for him/her'

(21) Iana mambava manggeh da oku

3SG bring mangosteen Prep 1SG

'He brought mangosteens for me'

(22) Jalms $i$ mambai pitis da iənə

Person DEF give money Prep him/her

'The person gave money to him/her'

(23) Amai manungkihas nyia da oku

Mother make water coconut Prep 1SG

'(My) mother made gree coconut-water for me'

The clauses in (16)-(19) are named the extended transitive because of having three core arguments while the examples in (20)-(23) are called the transitive clauses consisting of only two core arguments. The alternatives of clause structure from (16)-(19) to (20)-(21) are caused by the disappearance of the suffix marker $-k a n$. Thus, it can be concluded that the marker is used to increase the number of core arguments from the verbs with two core arguments into three-core arguments. Pay attention to the tree diagram 4 which shows the clause structure alternatives from ditransitive into mono-transitive predicates.

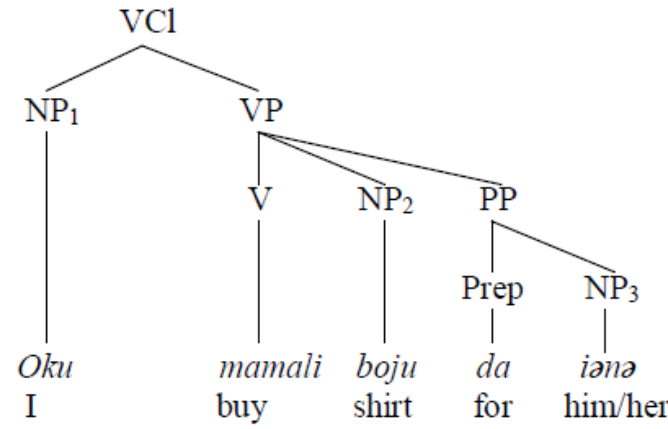

Tree Diagram4. Clause structure alternative from di-transitive into mono-transitive verbal predicates

\section{CONCLUSIONS}

It is concluded that the structure of clauses in SL consists of nonverbal and verbal predicates. Nonverbal structures may appear in adjectival, nominal, numerical predicate clauses, and in predicate 
clauses with prepositional phrases. The SL does not have copulative verbs and its verbal predicates of clause structure consist of intransitive, mono-transitive, and di-transititive (or sometimes called extended transitive). Semantically, there is only argument whose function is as the agent in the intransitive clause. If the verb that occupies the predicate position of the intransitive clause is a verb of situation (or non verbal predicate), the grammatical subject in the transitive clause generally becomes the agent; the grammatical object in the transitive clause is generally the patient. Subject as the core grammatical relation appears in the pre-verbal position of the canonical structure. An adverb can be inserted between pre-verbal and verbal arguments. In the canonical position, the pre-verbal argument becomes the subject so between the subject and its verb may have adverb. The object is the argument that directly follows the verbal or post-verbal argument in the canonical structure.

\section{ACKNOWLEDGEMENT}

This research was financially supported by a grant of BPPS DIKTI, Ministry of Research, Technology and Higher Education (Ministry of RISTEK DIKTI) provided to the first author. The authors thank the honourable informants for their significant assistance and comments on field-data. The authors also thank to the anonymous reviewers who gave their time to review this work and to Muhammad Ali Pawiro who delivered assistance in the proofreading and manuscript editing.

\section{REFERENCES}

[1] Comrie B. Language Universals and Linguistic Typology. Offord Basil Blakwell. (1995).

[2] Comrie B. "Causative Verb Formation and other Verb-Deriving Morphology" dalam T. Shopen (ed). Language Typology and Syntactic Description. Vol 33. Hal: 309-348. Cambridge: Cambridge University Press. (1985).

[3] Greeberg. J.H. Universal of Language. Massachusetts. The M.I.T. Press. (1963).

[4] Manurung, et.al. 'Beberapa Data Bahasa Siladang: Suatu Penelitian' (Khusus Fonologi dan Morfologi). Medan: Fakultas Sastra Universitas Sumatra Utara. (1978).

[5] Butar-Butar, M. et.al. 'Morfologi dan Sintaksis Bahasa Siladang'. Jakarta. Pusat Pembinaan dan Pengembangan Bahasa Departemen Pendidikan dan Kebudayaan. (1984).

[6] Pawiro M.A. and Siwi P. Karakteristik Tipologi Bahasa Siladang. (Laporan Penelitian). Medan: Fakultas Sastra UISU. (2005).

[7] Syarfina, T dan Sinar, T.S. "Prosodi Bahasa Siladang Sumatera Utara". Medan. Universitas Sumatra Utara. (2010).

[8] Verhaar, J.W.M. Pengantar Linguistik Jilid I. Yogyakarta: Gajah Mada University Press. (1989).

[9] Artawa K. "Ergativity and Balinese Syntax" (disertasi). Melbourne: La Trobe University. (1994).

[10] Artawa K. 'Ergativity and Balinese Syntax'. Dalam NUSA Vol 42-44. Jakarta: Pusat Kajian Bahasa dan Budaya. (1998).

[11] Suciati, Ni Luh Gede. 2000. "Aliansi Gramtikal dan Diatesis Bahasa Tetun Dialek Fehan: Sebuah Analisis Leksikal Fungsional" (tesis). Denpasar: Universitas Udayana. (2000).

[12] Arka I.W. "Beberapa Aspek Intransitif Terbelah pada Bahasa Nusantara". Makalah dipresentasikan pada Austronesia Formal Linguistics. (2003)

[13] Jufrizal. "Struktur Argumen dan Aliansi Gramatikal Bahasa Minangkabau" (diss.). Denpasar: Program Pascasarjana Universitas Udayana. (2004).

[14] Jufrizal. "Tipologi Gramatikal Bahasa Minangkabau. Padang: UNP Press. (2007).

[15] Jufrizal. "Fenomena Tipologi Gramatikal Bahasa Minangkabau: Akusatif, Ergatif atau Campur?" Leksika Vol 3. No.1 .14-28. Padang: Universitas Negeri Padang. (2009).

[16] Sawardi F.X. "Pivot dan Subjek dalam Kasus Bahasa Jawa". Semarang. Universitas Sebelas Maret. (2007).

[17] Yusdi M. "Relasi Gramatikal Bahasa Melayu Klasik dalam Hikajat Abdullah" E-Journal of Linguistic Vol-2 No.1 Denpasar: Program Pascasarjana Universitas Udayana. (2008).

[18] Basaria I. "Relasi dan Peran Gramatikal dalam Bahasa Pakpak Dairi: Kajian Tipologi" (diss.). Program Pascasarjana.Medan: Universitas Sumatera Utara. (2011).

[19] Sukendra. "Struktur Klausa Bahasa Sabu: Kajian Tipologi Bahasa" (disertasi). Denpasar: Program Pascasarjana Universitas Udayana. (2012).

[20] Budiarta I.W. "Tipologi Sintaksis Bahasa Kemak" (disertasi). Denpasar: Program Pascasarjana Universitas Udayana. (2013).

[21] Kridalaksana H. Introduction to Word Formation and Word Classes in Indonesia. Depok: Fakultas Sastra Universitas Indonesia Press. (1998). 
[22] Verhaar J.W.M. Pengantar Linguistik Jilid I. Yogyakarta: Gajah Mada University Press. (1989).

[23] Lapoliwa Hans. Klausa Pemerlengkapan dalam Bahasa Indonesia. Yogyakarta: Kanisius. (1990).

[24] Elson B.F., Pickett V.B. Beginning Morphology and Syntax. Dallas. Texas: Summer Institute of Linguistics. (1983).

[25] Lyon J. Introduction to Theoretical Linguistics. Cambridge: Cambridge University Press. (1987).

[26] Van Valin Jr. R.D. and Randy J.L. Syntax: Structure, Meaning, and Function. Cambridge: Cambridge University Press. (1999/2002).

[27] Djajasudarma T.F. Metode Linguistik: Rancangan Metode Penelitian dan Kajian. Bandung: Eresco. (1993).

[28] Sudaryanto. Metode Linguistik. Yogyakarta: Gajah Mada University Press. (1986,1992).

[29] Mithun M. Who Shapes the Record, the Speaker and the Linguist. Dalam Newman, Paul and Martha Ratliff, Editors Linguistics Fieldwork. First Edition. Cambridge: Cambridge University Press. (2001).

[30] Mallinson G. and Blake B.J. Language Typology: Cross-Linguistic Study in Syntax. Amsterdam: North Holland Publishing Company. (1981).

[31] Haegeman L. and Gueron J. English Grammar: A Generative Perspective. Oxford: Blackwell Publishers. (1999).

[32] Nida E. Morphology: The Descriptive Analysis of Word.. Canada: The University of Michigan Press. (1970).

[33] Comrie B. "Linguistics Typology. Dalam Newmeyer, F.J (Ed.) Linguistics: The Cambridge Survey. Vol I. Hal: 447-467. Cambridge: Cambridge University Press. (1983, 1989).

[34] Sudaryanto. Metode dan Aneka Tehnik Analisis Bahasa. Yogyakarta: Duta Wacana University Press. (1993)

[35] Dixon R.M.W. Basic Linguistic Theory. Vol 2. Oxford: Oxford University Press. (2010).

\section{AUTHORS' BIOGRAPHY}

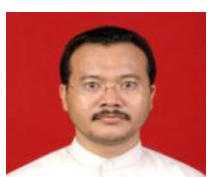

Purwanto Siwi, Ph.D. Candidate at the Post Graduate Department of Linguistics, Faculty of Cultural Sciences, University of Sumatera Utara, Medan, Indonesia. Currently, he works for the Faculty of Literature, Universitas Islam Sumatera Utara (UISU). He got his MA in Linguistics from Faculty of Arts, University of Delhi in 1998. He has written some papers in Linguistics and presented them nationally and internationally.

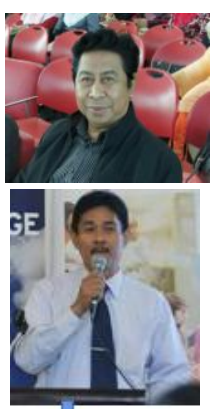

Prof. Paitoon M. Chaiyanara, Siwi's Promotor and becomes visiting professor at the Post Graduate Department of Linguistics, Faculty of Cultural Sciences, University of Sumatera Utara, Medan, Indonesia.

Dr. Eddy Setia, Siwi's First Promotor and is now appointed as the head of Post Graduate Department of Linguistics, Faculty of Cultural Sciences, University of Sumatera Utara, Medan, Indonesia.

Dr. Masdiana Lubis, Siwi's Second Promotor and one of teaching staffs at the Post Graduate Department of Linguistics, Faculty of Cultural Sciences, University of Sumatera Utara, Medan, Indonesia.

Citation: Purwanto Siwi, Paitoon M. Chaiyanara, Eddy Setia, Masdiana Lubis, "Verbal Clause in Siladang Language." International Journal of Humanities Social Sciences and Education (IJHSSE), vol 4, no. 10, 2017, pp. 37-46. doi:http://dx.doi.org/10.20431/2349-0381.0410005.

Copyright: () 2017 Authors. This is an open-access article distributed under the terms of the Creative Commons Attribution License, which permits unrestricted use, distribution, and reproduction in any medium, provided the original author and source are credited. 